\title{
THE MICROSTRUCTURE OF METASTABLE AUSTENITE IN X5CrNi18-10 STEEL AFTER ITS STRAIN-INDUCED MARTENSITIC TRANSFORMATION
}

\author{
MIKROSTRUKTURA METASTABILNEGA AVSTENITA PO \\ PRETVORBI V NAPETOSTNO INDUCIRANI MARTENZIT V \\ JEKLU X5CrNi18-10
}

\author{
Agnieszka Kurc-Lisiecka', Wojciech Ozgowicz ${ }^{2}$, Elżbieta Kalinowska-Ozgowicz ${ }^{3}$, \\ Wojciech Maziarz ${ }^{4}$ \\ ${ }^{1}$ Rail Transport Department, University of Dabrowa Gornicza, Cieplaka Str. 1C, 41-300 Dabrowa Gornicza, Poland \\ ${ }^{2}$ Institute of Engineering Materials and Biomaterials, Silesian University of Technology, Gliwice, Poland \\ ${ }^{3}$ Fundamentals of Technology Faculty, Lublin University of Technology, Nadbystrzycka Str. 38, 20-618 Lublin, Poland \\ ${ }^{4}$ Institute of Metallurgy and Materials Science of the Polish Academy of Sciences, Reymonta Str. 25, 30-059 Krakow, Poland \\ akurc@wp.pl
}

Prejem rokopisa - received: 2015-05-19; sprejem za objavo - accepted for publication: 2015-11-05

doi:10.17222/mit.2015.102

The performed investigations concerned the influence of the degree and temperature of deformation on the microstructure of metastable austenite in the stainless steel X5CrNi18-10 after its strain-induced martensitic transformation. Samples of steel strip were cold rolled within a degree of deformation from $20 \%$ to $70 \%$ and stretched at a low temperature of $-196{ }^{\circ} \mathrm{C}$. The microstructure was observed by means of scanning electron microscopy (SEM) and transmission electron microscopy (TEM, HREM). It wasen found that after cold rolling with a small degree of deformation (20\%) in the tested steel, generally a single-phase microstructure of the matrix $\gamma$ is found with a high density of dislocations and numerous deformation bands morphologically characteristic of stainless steel with a low stacking-fault energy. After rolling with a $50 \%$ thickness reduction, however, the microstructure displayed deformation twins as well as refined morphologic formations of the phase $\alpha$, mostly localized in the vicinity of the grain boundaries of the metastable matrix $\gamma$, and also trace amounts of carbide precipitates. In samples stretched at a temperature of $-196{ }^{\circ} \mathrm{C}$ the microstructure of the matrix displayed a considerable density of dislocations with lath areas of the martensite $\alpha$ ' and precipitations of the carbides $\mathrm{M}_{23} \mathrm{C}_{6}$. Moreover, the tested steel revealed a crystallographic dependence of the planes and directions on the identified phases $\gamma$ and $\alpha$, corresponding to dependences of the Kurdjumov-Sachs type, independent of the method and temperature of the plastic deformation. Tests carried out in the TEM proved that the typical sites of nucleation induced by the plastic deformation of martensite are the shear bands, particularly their intersection. The preferred mechanism of transformation, observed in the conditions of cold rolling is, however, a direct transformation of the type $\gamma$ (fcc) $\rightarrow \alpha^{\prime}$ (bcc).

Keywords: austenitic stainless steels, cold rolling, microstructure, phase transformation, strain- induced martensite

Izvedene so bile preiskave vpliva temperature in stopnje deformacije na mikrostrukturo metastabilnega avstenita po njegovi pretvorbi v napetostno inducirani martenzit v jeklu X5CrNi18-10. Vzorci v obliki trakov so bili hladno valjani s stopnjo deformacije od $20 \%$ do $70 \%$ in natezani pri nizki temperaturi $-196{ }^{\circ} \mathrm{C}$. Mikrostruktura je bila opazovana s pomočjo vrstične elektronske mikroskopije (SEM) in s presevno elektronsko mikroskopijo (TEM, HREM). Ugotovljeno je, da je po hladnem valjanju $\mathrm{z}$ majhno stopnjo deformacije $(20 \%) \mathrm{v}$ preizkušanem jeklu dobljena enofazna mikrostruktura $\mathrm{z}$ osnovo $\gamma$, $\mathrm{z}$ visoko gostoto dislokacij in številnimi deformacijskimi pasovi, ki so morfološka značilnost nerjavnega jekla z nizko energijo napake zloga. Po valjanju s $50 \%$ zmanjšanjem debeline, se v mikrostrukturi pokažejo deformacijski dvojčki, kot tudi drobni nastanki faze $\alpha$ ', večinoma v bližini mej zrn metastabilne osnove $\gamma$ in tudi sledi izločkov karbidov. V vzorcih natezno obremenjenih pri temperaturi $-196{ }^{\circ} \mathrm{C}$ je mikrostruktura osnove pokazala precejšnjo gostoto dislokacij z latastimi področji martenzita $\alpha$ ' in izločki karbidov $\mathrm{M}_{23} \mathrm{C}_{6}$. Poleg tega je preiskovano jeklo pokazalo kristalografsko odvisnost usmerjenosti ravnin in ploskev $v$ identificiranih fazah $\gamma$ in $\alpha^{\prime}$, ustrezno odvisnosti vrste Kurdjumov-Sachs, neodvisno od metode in temperature plastične deformacije. Preiskave izvedene na TEM so potrdile, da so značilna mesta nukleacije martenzita, inducirane s plastično deformacijo, strižni pasovi, posebno še njihova križanja. Prednostni mehanizem premene, opažene pri hladnem valjanju, je neposredna premena vrste $\gamma$ (fcc) $\rightarrow \alpha^{\prime}(\mathrm{bcc})$

Ključne besede: avstenitna nerjavna jekla, hladno valjanje, mikrostruktura, fazna premena, napetostno inducirani martenzit

\section{INTRODUCTION}

Austenitic stainless steels are widely used in many engineering applications, such as in the chemical, machinery, food, automotive, nuclear and shipbuilding industries, due to their excellent corrosion resistance, weldability, and mechanical properties. However, some of these austenitic steels with a lower content of $\mathrm{Ni}$ can undergo a transformation to martensite during cold working. ${ }^{1}$ A different martensite morphology can be formed due to these processes, mainly strain-induced or stress-induced martensite. ${ }^{2}$ In austenitic stainless steels two types of martensite can form spontaneously, i.e., body-centered cubic (bcc) martensite $\alpha^{\prime}$ and hexagonal close-packed (hcp) martensite $\varepsilon$. The amount of $\varepsilon$ and/or $\alpha$ ' martensite depends on the chemical composition, stacking-fault energy, phase stability and processing parameters, such as stress state, temperature, strain rate. 
During the deformation process different transformation sequences take place, such as: $\gamma \rightarrow \varepsilon \rightarrow \alpha^{\prime}$ or $\gamma \rightarrow \alpha^{\prime}$. In the transformation mode $\gamma \rightarrow \varepsilon \rightarrow \alpha^{\prime}, \varepsilon$ martensite acts as the precursor phase of $\alpha^{\prime}$. The formation of $\alpha^{\prime}$ is closely related to the shear bands, which are planar defects associated with the overlapping of stacking faults on $\{111\} \gamma$. Depending on the nature of the overlapping, twins, $\varepsilon$ martensite or stacking-fault bundles may be formed. Twins are formed when stacking faults overlap on successive $\{111\}$ planes, whereas $\varepsilon$ martensite is generated if the overlapping of the stacking faults occurs on alternate $\{111\}$ planes. Stacking-fault bundles arise from the irregular overlapping of stacking faults. ${ }^{1-6}$

The presence of deformation-induced martensite may be a harmful phenomenon and may cause a delayed cracking of deep-drawn austenitic stainless-steel components. On the other hand, the formation of martensite resulting from the plastic deformation of metastable austenite is of great interest for the production of highstrength and ductile austenitic stainless steels. ${ }^{2,3}$

The aim of the present study was to analyze the morphological details of strain-induced martensite in cold-rolled $\mathrm{Cr}-\mathrm{Ni}$ steel.

\section{MATERIAL AND EXPERIMENTAL PROCEDURE}

The investigations concerned austenitic stainless steel of the type X5CrNi18-10 in compliance with PN-EN 10088:1-2007 ${ }^{7}$ with the chemical composition quoted in Table 1. The input material in the form of steel strip, $2 \mathrm{~mm}$ thick, $40 \mathrm{~mm}$ in width and $700 \mathrm{~mm}$ long was supersaturated in water after its austenitizing for $1 \mathrm{~h}$ at a temperature of $1100{ }^{\circ} \mathrm{C}$ and cold rolled with a $20 \%$, $50 \%$ and $70 \%$ thickness reduction. After rolling with a draft of $70 \%$, samples of the tested steel were subjected to a tensile test at a low temperature of $-196{ }^{\circ} \mathrm{C}$ with a strain rate $\dot{\varepsilon}$ of about $10^{-5} \mathrm{~s}^{-1}$.

Table 1: Chemical composition of the investigated steel

Tabela 1: Kemijska sestava preiskovanih jekel

\begin{tabular}{|c|c|c|c|c|c|c|c|c|c|}
\hline \multicolumn{1}{|c|}{ Elements content, in mass fractions $(w / \%)$} \\
\hline $\mathrm{C}$ & $\mathrm{Mn}$ & $\mathrm{Si}$ & $\mathrm{P}$ & $\mathrm{S}$ & $\mathrm{Cr}$ & $\mathrm{Ni}$ & $\mathrm{Ti}$ & $\mathrm{Al}$ & $\mathrm{Fe}$ \\
\hline 0.024 & 1.32 & 0.43 & 0.028 & 0.005 & 18.53 & 7.8 & 0.010 & 0.01 & bal. \\
\hline
\end{tabular}

The hardness measurements of the investigated cold-rolled steel were carried out with a microhardness tester FM 700 produced by Future-Tech (Japan), according to the standard PN-EN ISO 6507-1:2007. ${ }^{8}$ The hardness was also determined in the case of the sample after $70 \%$ degree and stretched at a low temperature of $-196{ }^{\circ} \mathrm{C}$ with a strain rate $\dot{\varepsilon}$ of about $10^{-5} \mathrm{~s}^{-1}$. The measurements were made using the Vickers method on metallographic samples with a load of $50 \mathrm{~N}$ for a time of $30 \mathrm{~s}$.

The microstructural investigations were performed with scanning (SEM) and transmission electron micro- scopy, as well as high-resolution electron microscopy (HREM). Applying SEM, a metallographic polished section after cold rolling with a draft of $20 \%$ and stretching at the temperature of liquid nitrogen was detected. These observations were made by means of SEM of the SUPRA type from Zeiss (Germany) with a magnification of $15.000 \times$.

The section that was mechanically polished was etched in the reagent Mi17Fe. ${ }^{9}$ TEM observations were carried out using thin foils on the samples of strip after cold rolling with a draft of $50 \%$, and on samples stretched at a temperature of $-196{ }^{\circ} \mathrm{C}$. The preparation of the foils comprised a cutting out of disks, $3 \mathrm{~mm}$ in diameter, from a strip with a thickness of 1.0 and $0.6 \mathrm{~mm}$, grinding with abrasive paper until the samples reached a thickness of $0.1 \mathrm{~mm}$. The Tenupol-5 double jet electropolisher was used for thin foil preparation from the samples in an electrolyte containing nitric acid and methanol (1:3). The microstructure was observed by means of TEM of the type Technai $\mathrm{G}^{2}$ F20 applying an accelerating voltage of $200 \mathrm{kV}$ equipped with high-angle annular dark-field (HAADF) and energy-dispersive (EDS) detector. The phases were identified based on electron diffraction. The procedure was aided by the
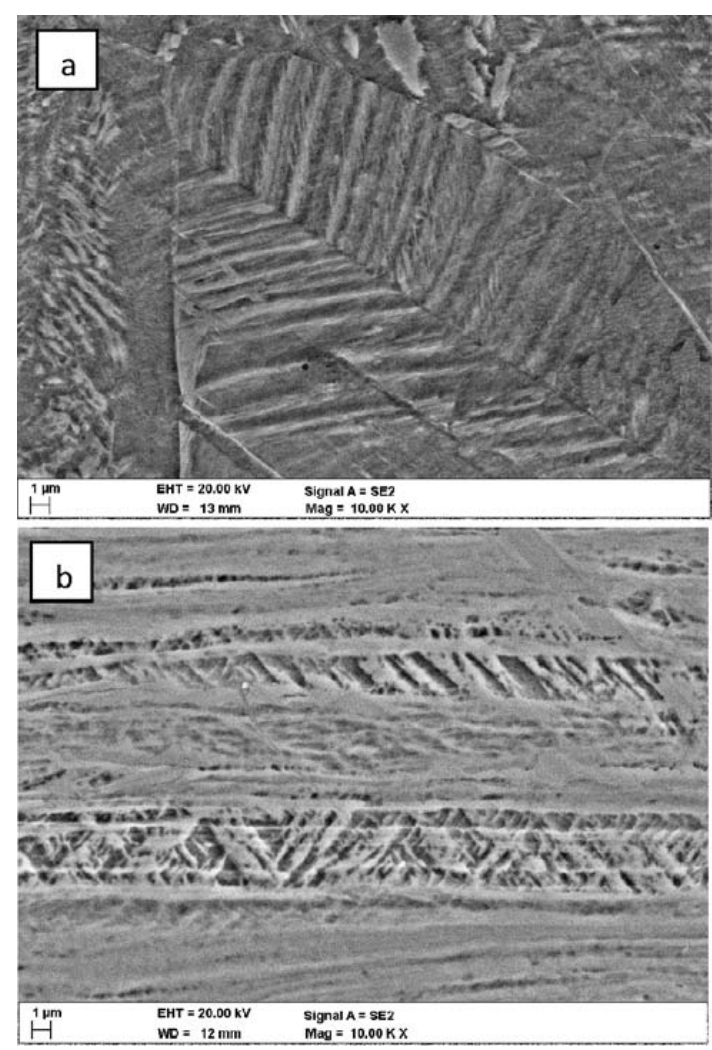

Figure 1: Microstructure of investigated steel X5CrNi18-10: a) after $20 \%$ of deformation, b) after cold-rolling with $70 \%$ and tensile test at $-196{ }^{\circ} \mathrm{C}$, etching- Mi17Fe

Slika 1: Mikrostruktura preiskovanega jekla X5CrNi18-10: a) po 20 $\%$ deformaciji, b) po hladnem valjanju s $70 \%$ in nateznim preizkusom pri $-196{ }^{\circ} \mathrm{C}$, jedkano z Mi17Fe 

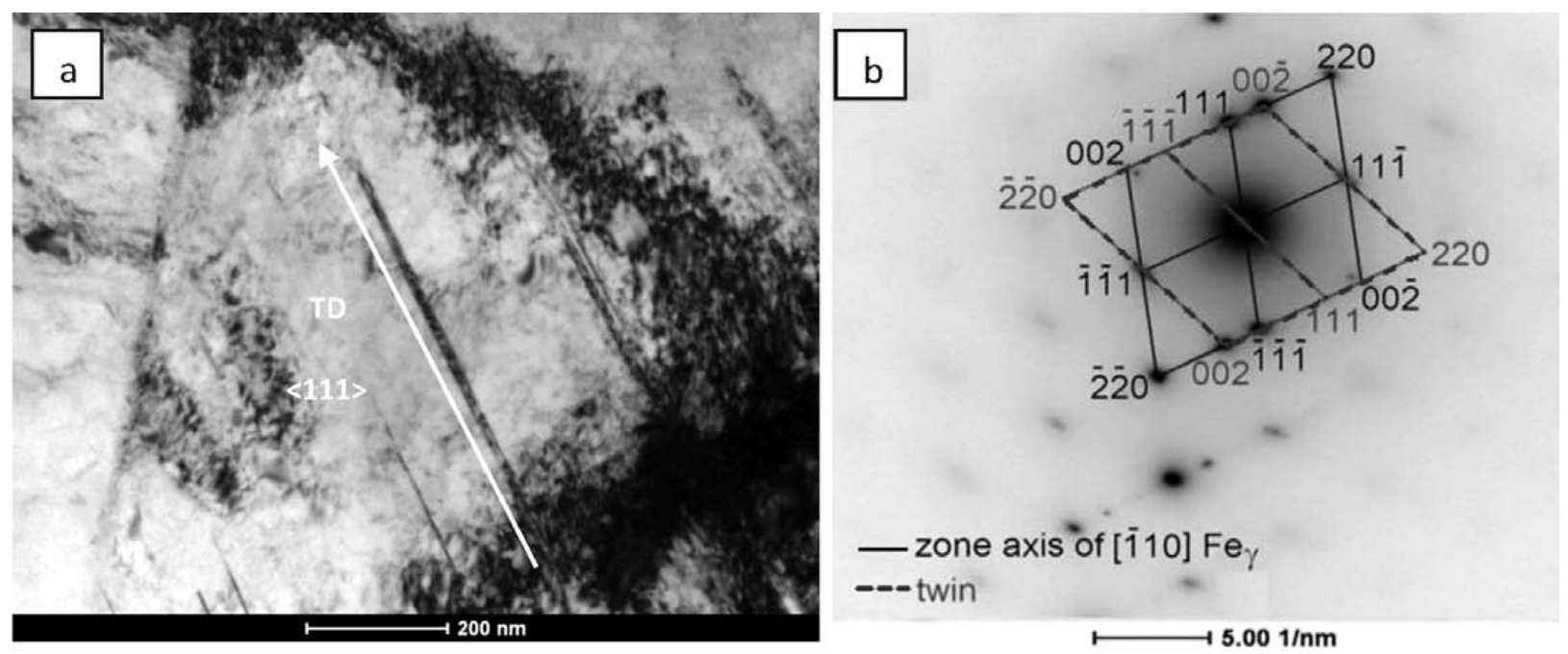

Figure 2: TEM micrograph of X5CrNi18-10 steel after $50 \%$ of deformation: a) a band of austenite containing microtwins, b) diffraction pattern Slika 2: TEM-posnetek jekla X5CrNi18-10 po $5 \%$ deformaciji: a) pas avstenita, ki vsebuje mikrodvojčke, b) uklonska slika

computer software Gatan and a crystallographic database.

\section{RESULTS AND DISCUSSION}

In the supersaturated state the investigated steel displays a single-phase austenite structure with a diameter of the average grains in the matrix $\gamma$ amounting to about $75 \mu \mathrm{m}$ and a hardness of about $125 \mathrm{HV} 0.5$, containing many annealed twins and single clusters of non-metallic inclusions. After cold rolling in the range 20-30\% metallographically distinctly elongated grains of the matrix $\gamma$ with a hardness of 323 HV5 (Table 2) could be detected with numerous effects of work hardening in the form of fine parallel and intersected lines and slip bands, as well as shear bands, which are probably sites of martensite $\alpha$ ' nucleation.

Table 2: Results of the hardness measurement of the investigated cold-rolled and stretched steel

Tabela 2: Meritve trdote preiskovanih hladno valjanih in natezanih jekel

\begin{tabular}{|c|c|c|c|c|c|}
\hline \multirow{3}{*}{ No. } & \multirow{3}{*}{ Material condition } & \multirow{2}{*}{\multicolumn{3}{|c|}{$\frac{\text { Hardness, HV }}{\text { Number of measurement }}$}} & \multirow{3}{*}{$\begin{array}{l}\text { Hard- } \\
\text { ness, } \\
H V \\
\end{array}$} \\
\hline & & & & & \\
\hline & & 1 & 2 & 3 & \\
\hline 1 & supersaturated & 144.7 & 148.5 & 145.8 & 146.3 \\
\hline 2 & cold rolled $z_{\mathrm{h}}=20 \%$ & 321.5 & 322.7 & 325.9 & 323.4 \\
\hline 3 & cold rolled $z_{\mathrm{h}}=50 \%$ & 411.5 & 410.8 & 408.7 & 410.3 \\
\hline 4 & cold rolled $z_{\mathrm{h}}=70 \%$ & 418.5 & 417.4 & 418.6 & 418.1 \\
\hline 5 & $\begin{array}{c}\text { cold rolled with } \\
z_{\mathrm{h}}=70 \% \text { and } \\
\text { stretched at }-196^{\circ} \mathrm{C}\end{array}$ & 460.1 & 461.3 & 459.2 & 460.2 \\
\hline
\end{tabular}

The results of the observation of the microstructure of the investigated steel after cold-rolling with a degree of deformation of $20 \%$ and $70 \%$ and after stretching at a temperature of $-196{ }^{\circ} \mathrm{C}$ carried out on a scanning electron microscope (SEM) are presented in the micrographs

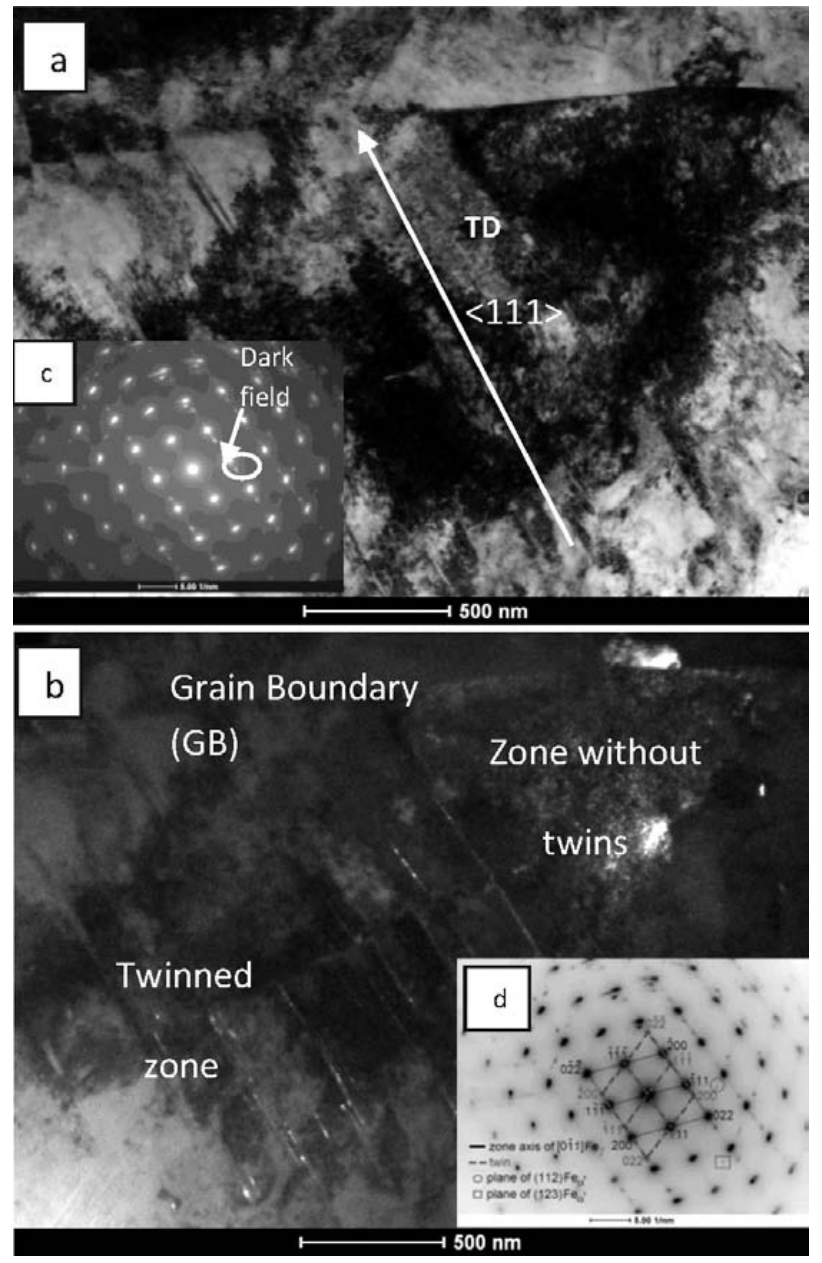

Figure 3: TEM micrograph structure of $\mathrm{X} 5 \mathrm{CrNi18}-10$ steel after $50 \%$ of deformation: a) microstructure of the matrix $\gamma$ containing microtwins and martensite $\alpha^{\prime}$, b) dark field taken of reflection (200) $\gamma$, c), d) diffraction pattern

Slika 3: TEM-posnetek strukture jekla X5CrNi18-10 po $50 \%$ deformaciji: a) mikrostruktura osnove $\gamma$, ki vsebuje mikrodvojčke in martenzit $\alpha^{\prime}$, b) temno polje pri odsevu (200) $\gamma$, c), d) uklonska slika 

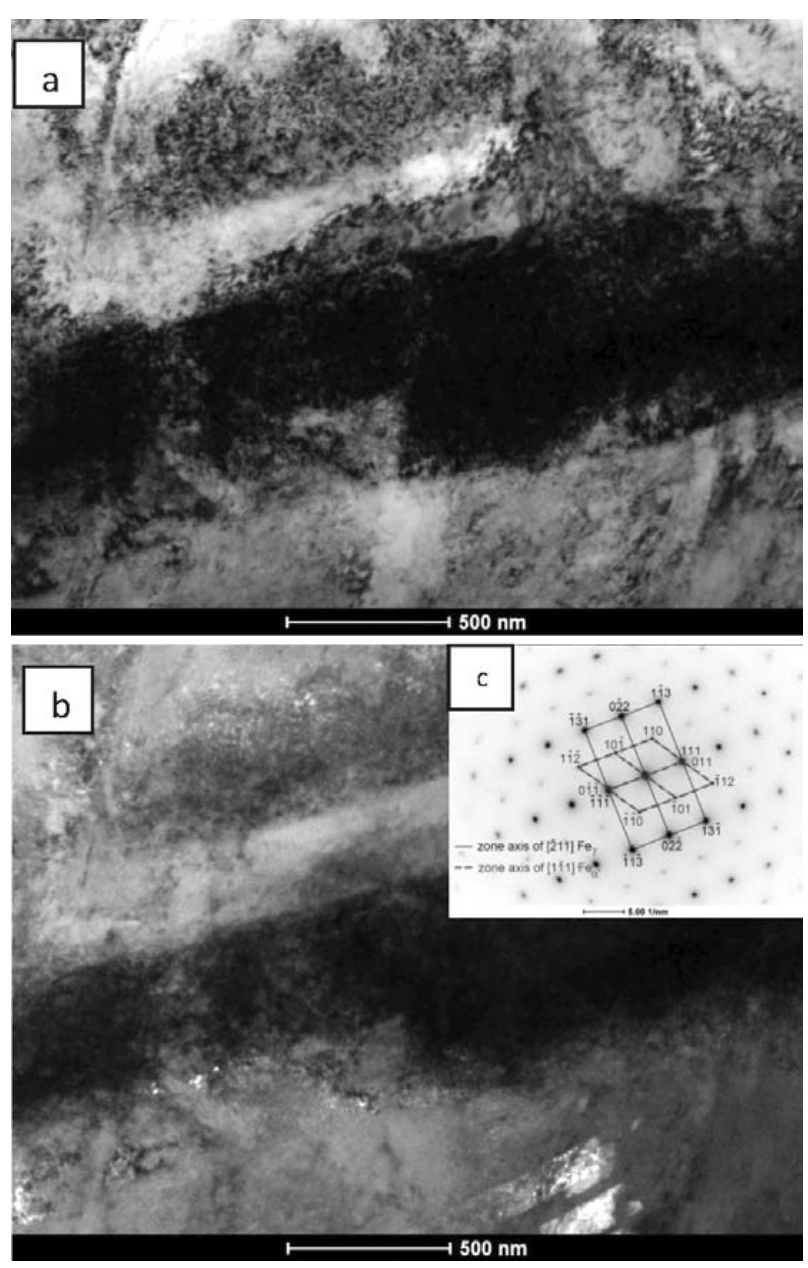

Figure 4: TEM micrograph structure of X5CrNi18-10 steel after 50\% of deformation: a) subgrain of austenite containing a high density of dislocations and $\alpha^{\prime}$, bright field, b) dark field taken of the reflection (110) $\alpha$ ', c) diffraction pattern

Slika 4: TEM-posnetek strukture jekla $\mathrm{X} 5 \mathrm{CrNi18}-10$ po $50 \%$ deformaciji: a) podzrna avstenita vsebujejo veliko gostoto dislokacij in $\alpha^{\prime}$, svetlo polje, b) temno polje pri odsevu $(110) \alpha^{\prime}$, c) uklonska slika
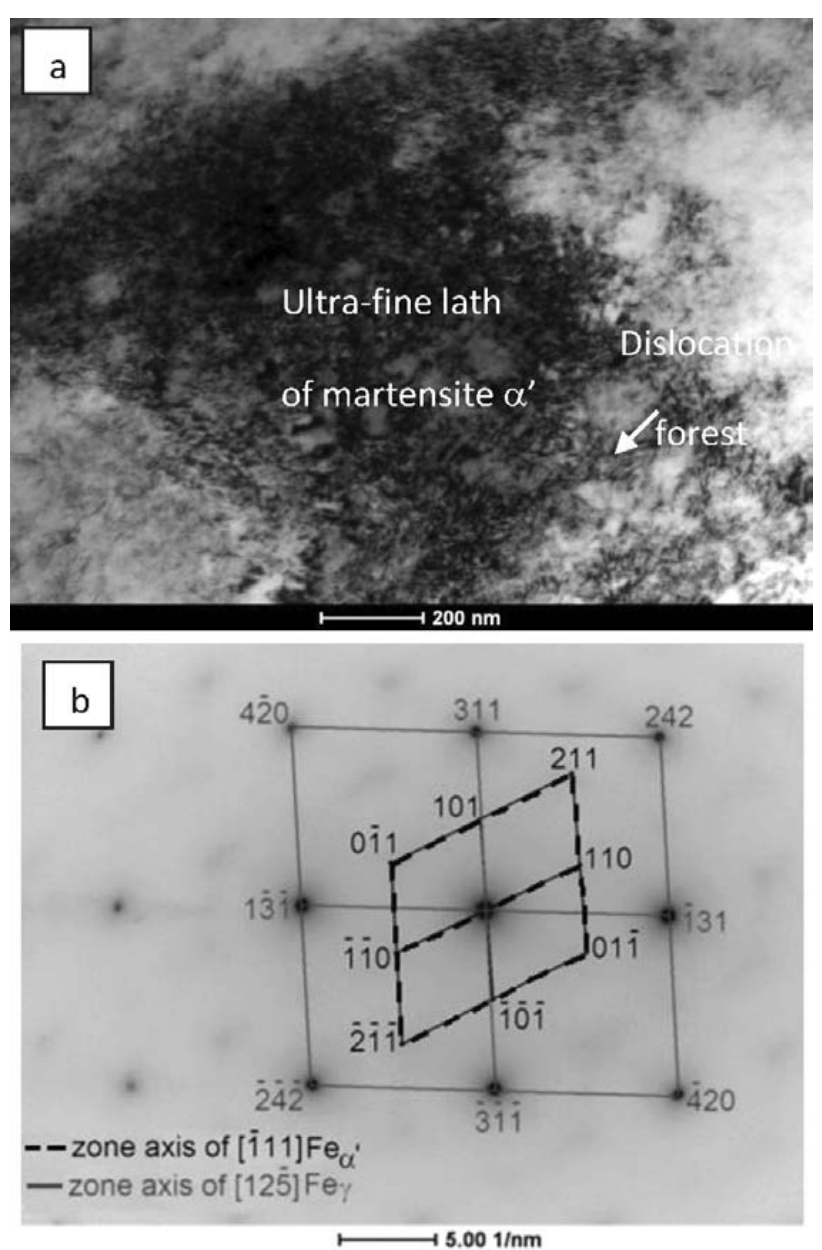

Figure 5: TEM micrograph structure of X5CrNi18-10 steel after 50\% of deformation: a) cell microstructure of austenite containing a variable dislocation density and ultra-fine lath of martensite $\alpha^{\prime}, \mathrm{b}$ ) diffraction pattern

Slika 5: TEM-posnetek strukture jekla X5CrNi18-10 po 50\% deformaciji: a) celična mikrostruktura avstenita vsebuje različno gostoto dislokacij in ultra drobni latasti martenzit $\alpha^{\prime}$, b) uklonska slika
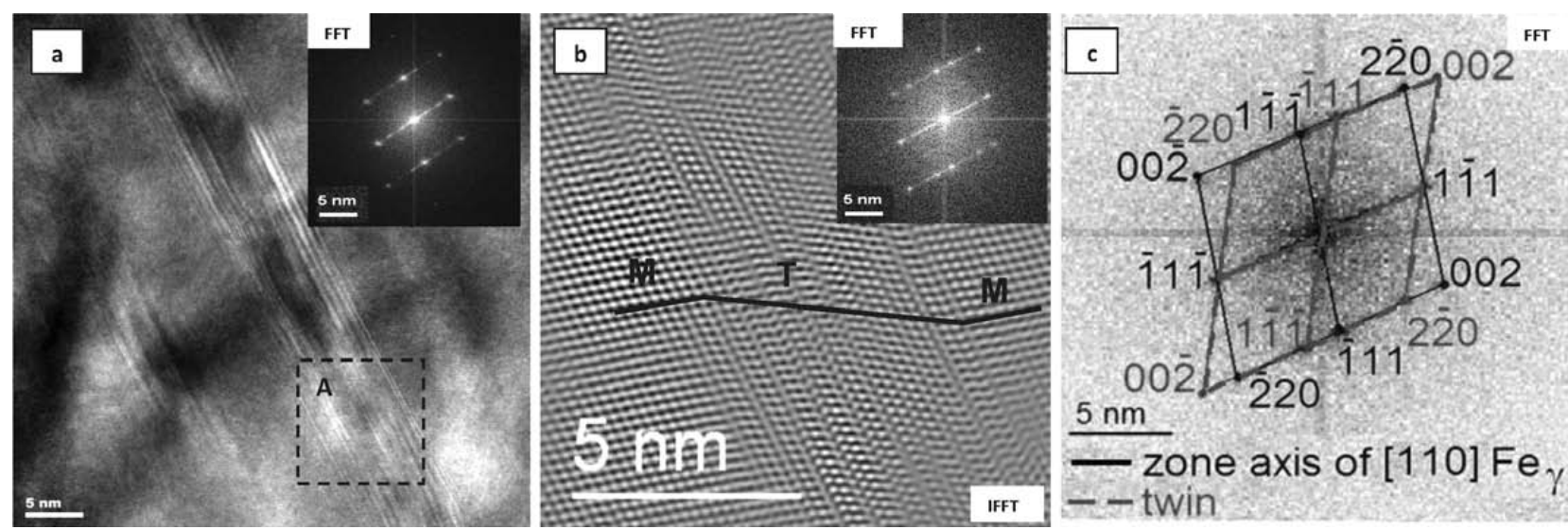

Figure 6: High-resolution (HREM) micrograph: a) dislocation structure of the matrix $\gamma$ of steel B after cold rolling ( $\left.\mathrm{z}_{\mathrm{h}}=50 \%\right)$ and Fourier transform (FFT), b) detail A of Figure 6a - modulated structure (IFFT) with microtwins bands and Fourier transform (FFT), c) solution of Fourier transform in Figures $\mathbf{6 a}$ and $\mathbf{6 b}$

Slika 6: Visokoločljivi posnetek (HREM): a) struktura dislokacij v osnovi $\gamma$ jekla B po hladnem valjanju $\left(\mathrm{z}_{\mathrm{h}}=50 \%\right)$ in Fourierjeva pretvorba (FFT), b) detajl A na Sliki 6a modulirana struktura (IFFT) s pasovi mikro tvojčkov in Fourierjeva pretvorba (FFT), c) rešitev Foirierjeve pretvorbe na Slikah 6a in $\mathbf{6 b}$ 
in Figure 1. In the structure of the steel, complex effects of deformation inside the grains $\gamma$ and at the boundaries are revealed (Figure 1a). Plastic deformation leads to a distinct elongation of the grains in the direction of rolling and to the formation of numerous slide bands and shear bands, in which probably the martensite $\alpha$ ' is localized (Figure 1b). The hardness of the examined steel increases with an increasing degree of deformation. With the increase of the cold rolling degree from $50 \%$ to 70 $\%$ the hardness of the investigated steel increases from 410 to 418 HV5, respectively (Table 2). As suggested in ${ }^{10,11}$ the twins, the dislocation density, the nucleation of martensite $\alpha^{\prime}$ and the increase of the volume fraction of martensite $\alpha$ ' phase during the transformation are the major factors influencing the hardness of the investigated steel.

Heterogeneities in the plastic deformation in the form of shear bands were found mainly in the case of larger, cold plastic working and tensile tests at reduced tempe-
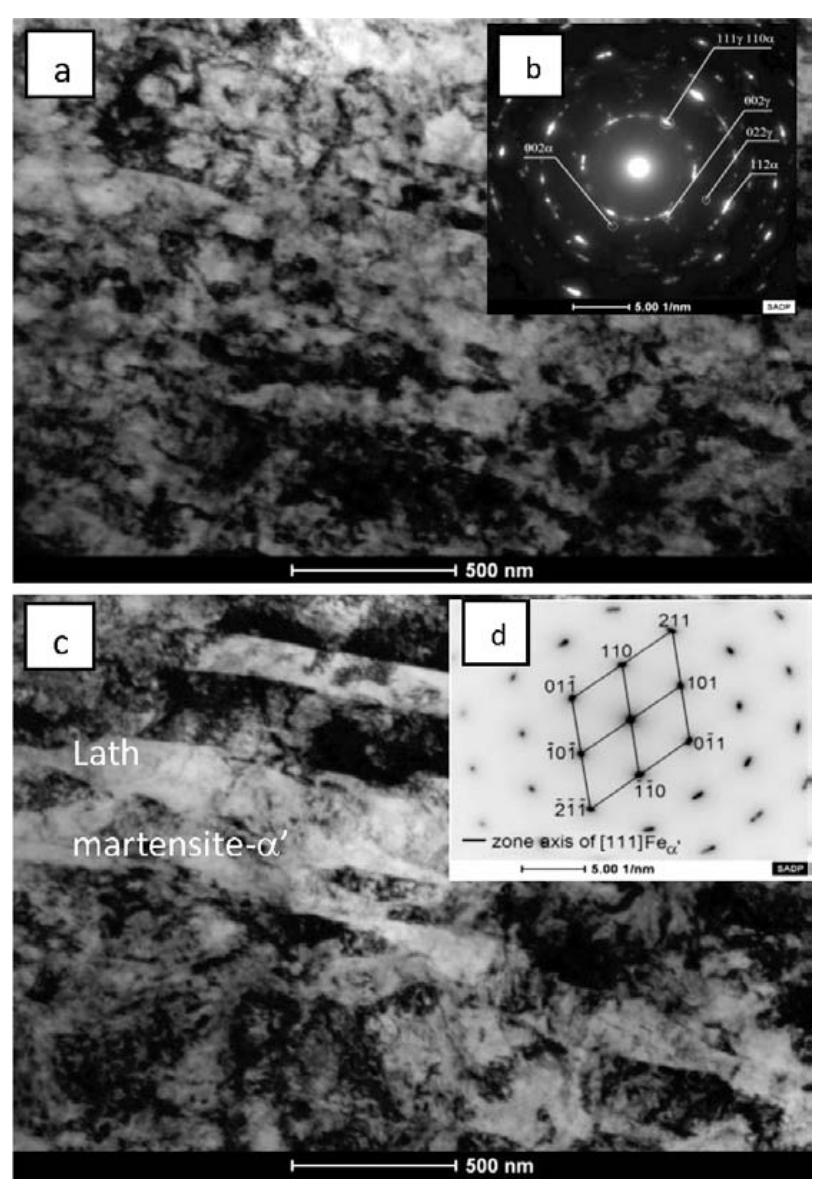

Figure 7: TEM micrograph structure of X5CrNi18-10 steel after cold-rolling with $70 \%$ and tensile test at temperature of $-196{ }^{\circ} \mathrm{C}$ with a strain rate of $10^{-5} \mathrm{~s}^{-1}$ : a) microstructure of elongated subgrain $\gamma$ with shear bands and heavily deformed lath of martensite $\alpha^{\prime}$, b) diffraction pattern from a, c) detail in Figure a, d) diffraction pattern from c

Slika 7: TEM-posnetek strukture jekla X5CrNi18-10 po hladnem valjanju, $70 \%$ in nateznem preizkusu pri $-196{ }^{\circ} \mathrm{C}$, s hitrostjo obremenjevanja $10^{-5} \mathrm{~s}^{-1}$ : a) mikrostruktura razpotegnjenih podzrn $\gamma$, s strižnimi pasovi in močno deformiranimi latami martenzita- $\alpha$ ', b) uklonska slika iz a, c) detajl iz slike a, d) uklonska slika iz c ratures up to $-196{ }^{\circ} \mathrm{C}$. Thin foils in the TEM revealed in steel $\mathrm{X} 5 \mathrm{CrNi18}-10$, cold rolled with a degree of deformation of $50 \%$, a cellular structure of dislocations of an austenitic matrix with a considerable density of dislocations with local twins (Figure 2). Also, single reflexes of the type (112) $\alpha^{\prime}$ and (123) $\alpha^{\prime}$ were observed, resulting from the martensitic phase $\alpha^{\prime}$ (Figure 3d). Based on electron diffraction and the dark-field method, the localisation of the deformation twins could be identified and the direction of twinning (TD) $<111>$ o was determined (Figures $\mathbf{2 b}$ and $\mathbf{3 d}$ ). In the microstructure of the investigated steel, highly elongated subgrain $\gamma$ and shearing bands dominate, and also an ultra-fine lath of martensite $\alpha$ ' with a characteristic dislocation forest (Figures 4 and 5). After cold rolling, observed in highresolution microscopy (HREM), the structure of the investigated steel reveals significant morphological details - on the nanometer scale - microbands of mechanical twinning as well as in the range of periodicity of the structure and its modulated character (Figure 6). The disclosed structural periodicity is reflected in the

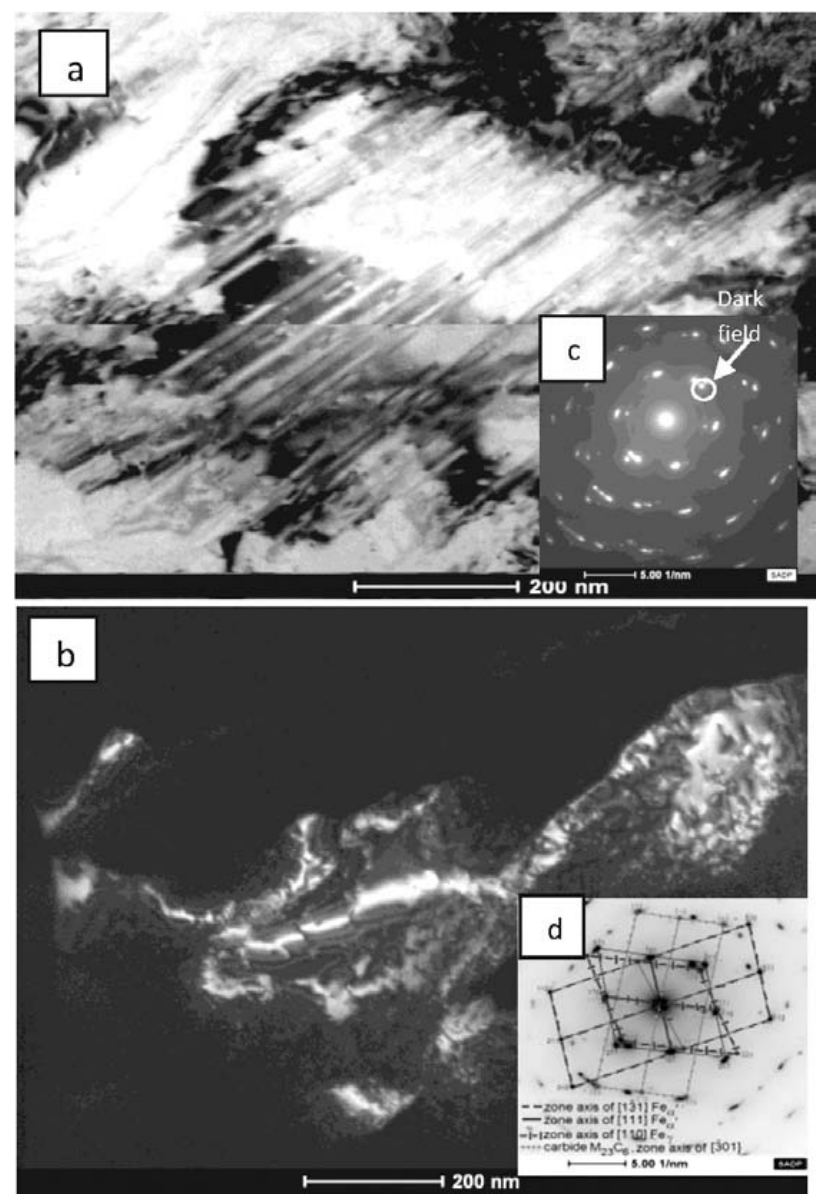

Figure 8: TEM micrograph structure of the $\mathrm{X} 5 \mathrm{CrNi18}-10$ steel: a) mechanical twins after $70 \%$ of deformation and tensile test at temperature of $-196{ }^{\circ} \mathrm{C}$ with $\dot{\varepsilon}=10^{-5} \mathrm{~s}^{-1}$, b) dark field in $\left.(002) \gamma, \mathrm{c}\right)$, d) diffraction pattern

Slika 8: TEM-posnetek strukture jekla X5CrNi18-10: a) mehanski dvojčki po $70 \%$ deformaciji in nateznem preizkusu pri $-196{ }^{\circ} \mathrm{C}, \mathrm{z}$ $\dot{\varepsilon}=10^{-5} \mathrm{~s}^{-1}$, b) temno polje pri (002) $\left.\gamma, \mathrm{c}\right)$, d) uklonska slika 
distribution of the atomic cores in the inverse Fourier transform (IFFT) (Figure 6c). High-resolution analysis of the sequence of microtwin bands (Figure 6a) and the corresponding Fourier transforms (FFT), comprising the entire area of HREM (Figure $\mathbf{6 b}$ ) and the marked area of the microstructure (Figure 6c) justify the statement that the visible and most intense reflections result mainly from the matrix $\gamma$ oriented as a zone axis of orientation [011] (Figure 6b). The additional weak reflections between the reflections of the planes $(002) \gamma$ and $(1 \overline{11}) \gamma$ can be attributed to the deformation twins (Figure $6 \mathbf{b}$ ). However, the presence of two weak reflections between the beam passing (000) and the planes ( $11 \overline{1}) \gamma$ and (11) 1$) \gamma$, dividing these distances into three equal parts with a length of $1 / 3(\overline{1} 1 \overline{1}) \gamma$, require an explanation. The presence of these reflections is not justified, however, in the case of twin orientations. ${ }^{12}$ In the transform (FFT) concerning the area of the band of microtwins (Figure 6c) there is a twin orientation with strong defocusing reflections in the planes $(1 \overline{1} 1) \gamma$. The inverse Fourier transform resulting from a transform (FFT) (Figure 6c) after filtering out the noise reveals that in the matrix $\gamma$ (M-matrix) a microtwin (T-twin) is located with a width of about $5 \mathrm{~nm}$, inside which the modulation effects are visible. Modulations are caused by periodic sequences of stacking faults occurring on the following planes $(1 \overline{1} 1) \gamma$ (Figure 6d).

The investigated cold-rolled steel with the degree of deformation of $70 \%$ and then subjected to a tensile test at strain rate $(\dot{\varepsilon})$ of about $10^{-5} \mathrm{~s}^{-1}$ at cryogenic temperatures $-196{ }^{\circ} \mathrm{C}$ displayed - similar to the cold-rolling - a subgrain structure elongated in the rolling direction with a high density of dislocations (Figure 7) and a considerably higher density of microtwinning (Figure 8). The hardness in these areas reaches about 460 HV5 (Table 2). The subgrain boundaries and the microtwins constitute potential locations for the phase $\alpha^{\prime}$, in the form of elongated lamellar areas with a width of approximately $0.1 \mu \mathrm{m}$ (Figure $7 \mathbf{b}$ ). It can be assumed that the nucleation of the phase $\alpha$ ' occurs preferentially in microtwins areas, mainly at their borders. It is significantly associated with the accumulation of the stress in a dislocation field, as suggested in ${ }^{11}$. Electron-diffraction analysis of the investigated steel not only provides evidence for the presence in its structure of martensitic phase $\alpha^{\prime}$ (Figures 3d, 4b, 5b, 7a, 7b and 8d) and $\mathrm{M}_{23} \mathrm{C}_{6}$ type carbides (Figure 8d), but also the occurrence of a crystallographic relationship between the matrix $\gamma$ and phase $\alpha^{\prime}$ type K-S, namely: (111) $\gamma \|$ (011) $\alpha^{\prime}$ and $<011>\gamma \|<111>\alpha$ ' (Figure 4b), also quoted with respect to similar grades of $\mathrm{Cr}-\mathrm{Ni}$ steel. ${ }^{11,13}$

\section{CONCLUDING REMARKS}

The structural investigations of the steel X5CrNi18-10 conducted in a TEM and the analysis of the obtained results allows us to draw the following conclusions:

The plastic deformation of the investigated steel X5CrNi18-10 induces the direct transformation of metastable austenite to the deformation martensite $\alpha^{\prime}$ of the (bcc) lattice during both the cold-rolling process, as well as the tensile test at temperatures lowered to -196 ${ }^{\circ} \mathrm{C}$.

The microstructure of the investigated steel after cold rolling with a degree of deformation in the range from $50 \%$ to $70 \%$ observed in the TEM, displays a high dislocation density in the matrix $\gamma$ and the presence of mechanical twins, as well as shearing bands in the area where the lamellar formations of the martensite $\alpha$ ' phase nucleate.

The cold rolling and stretching at low temperature of the austenitic stainless-steel sheets resulted in the occurrence of the strain-induced $\gamma \rightarrow \alpha$ ' phase transformation. During plastic deformation the volume fraction of martensite $\alpha$ ' phase increases, which causes the hardening of the investigated steel. The hardness of the cold-rolled steel within the draft from $20-70 \%$ is from the range 323-418 HV5, whereas in the case of samples after $70 \%$ degree of cold rolling and stretching at $-196{ }^{\circ} \mathrm{C}$ it is about 460 HV5.

High-resolution electron microscopy (HREM) of the microstructure revealed essential morphological details of the resulting microbands of twins on the nanometer scale. The application of Fourier's reverse transform (IFFT) indicated a periodicity of the analyzed structure and its modulated character in the range of appearing sequentially, the local disorder of the crystalline lattice.

The transformations $\gamma \rightarrow \alpha$ ' of the investigated steel induced by plastic deformation indicate a typical crystallographic relationship between austenite and martensite $\alpha$ ' given by Kurdjumov-Sachs, in the form: $(111)_{\gamma} \|(011)_{\alpha^{\prime}}$ and $<011>_{\gamma} \|<111>_{\alpha}$.

\section{Acknowledgements}

The authors gratefully acknowledge financial support from the research project: Innovative sanitary sewage system DEMONSTRATOR + NCBR under the contract No. UOD-DEM-1-591/001.

\section{REFERENCES}

${ }^{1}$ K. H. Lo, C. H. Shek, J. K. L. Lai, Morphologies and characteristics of deformation induced martensite during tensile deformation of 304 LN stainless steel, Materials Science and Engineering, 65R (2009) 4-6, 39-104, doi:10.1016/j.msea.2007.09.005

${ }^{2}$ A. Das, S. Sivaprasad, M. Ghosh, P. C. Chakraborti, S. Tarafder, Morphologies and characteristics of deformation induced martensite during tensile deformation of $304 \mathrm{LN}$ stainless steel, Materials Science and Engineering, 486A (2008), 283-286, doi:10.1016/ j.msea.2007.09.005

${ }^{3}$ J. Huang, X. Ye, Z. Xu, Effect of Cold Rolling on Microstructure and Mechanical Properties of AISI 301LN Metastable Austenitic Stain- 


\section{A. KURC-LISIECKA et al.: THE MICROSTRUCTURE OF METASTABLE AUSTENITE IN X5CrNi18-10 STEEL ...}

less Steels, Journal of Iron and Steel Research International, 19 (2012) 10, 59-63, doi:10.1016/S1006-706X(12)60153-8

${ }^{4}$ C. J. Gunter, R. P. Reed, Transaction of American Society for Metals, 55 (1962) 3, 399-419

${ }^{5}$ S. Rajasekhara, L. P. Karjalainen, A. Kyröläinen, P. J. Ferreira, Microstructure evolution in nano/submicron grained AISI 301LN stainless steel, Materials Science and Engineering, 527A (2010), 1986-1996, doi:10.1016/j.msea.2009.11.037

${ }^{6} \mathrm{~T}$. Angel, Journal of the Iron and Steel Institute, 177 (1954), 165-174

${ }^{7}$ European Standard, Stainless Steels - Part 1: List of stainless steels, Polish version PN-EN 10088:1-2007

${ }^{8}$ European Standard, Metals. Hardness measurements made by Vickers's method, Polish version PN-EN ISO 6507-1:2007

${ }^{9}$ ASTM E407, Standard Practice for Microetching Metals and Alloys
${ }^{10}$ W. S. Lee, C. F. Lin, The morphologies and characteristics of impact-induced martensite in 304L stainless steel, Scripta Materialia, 43 (2000) 8, 777-782, doi:10.1016/S1359-6462(00)00487-5

${ }^{11} \mathrm{~J}$. A. Venables, The martensite transformation in stainless steel, Philosophical Magazine, 73 (1962) 7, 35-44, doi:10.1080/ 14786436208201856

${ }^{12}$ W. Maziarz, Structure changes of $\mathrm{Co}-\mathrm{Ni}-\mathrm{Al}$ ferromagnetic shape memory alloys after vacuum annealing and hot rolling, Journal of Alloys and Compounds, 448 (2008) 1-2, 223-226, doi:10.1016/ j.jallcom.2006.12.044

${ }^{13}$ M. Blicharski, S. Gorczyca, Structural inhomogeneity of deformed austenitic stainless steel, Metal Science, 12 (1978) 7, 303-312, doi:10.1179/msc.1978.12.7.303 